\title{
The Expanding Security Agenda: Challenges for Transition States
}

\author{
Elena Kovalova *
}

\begin{abstract}
Since the end of the Cold War, transnational organized crime and corruption have persistently plagued the post-communist states in Central and Eastern Europe. Facilitation of travel and trade regimes in Europe has provided criminal organizations with a broader scope to expand their businesses and to invest and profit through such practices. The fall of living standards and growth of unemployment in the post-communist economies - along with the promotion of free movement of goods, services, and people in the enlarging European Union (EU) - produced new forms of organized crime in the region, particularly a modern-day equivalent of slavery that is known as trafficking in persons (TIP). The novelty of the crime, combined with the corruption of unreformed law enforcement agencies in transition states and the transnational nature of TIP have increased the need for international cooperation to fight it effectively. Based on an analysis of TIP in South Eastern European (SEE) and Eastern European states, this article attempts to assess the patterns of human trafficking in the region, determine links between corruption and trafficking, and identify possible networks for counter-trafficking activities in the region.
\end{abstract}

Keywords: transnational crime, trafficking in persons, corruption, transition, security sector reform, South Eastern Europe, Western New Independent States

\section{Introduction}

Trafficking in persons (TIP) is a crime that has complex attributes - it is a problem that exists on several levels and in multiple dimensions. ${ }^{1}$ TIP could be addressed as an organized crime concern, or as a human rights issue, or as a labor- or security-related problem. In addition to its complex nature, the issue of human trafficking, by its very nature, has transnational characteristics, almost always involving several states. The transnational na-

Dr. Elena Kovalova is a professor of national security studies at the George C. Marshall European Center for Security Studies in Garmisch-Partenkirchen.

For the purposes of this essay, trafficking in persons (TIP) is defined according to the Protocol to Prevent, Suppress and Punish Trafficking in Persons, Especially Women and Children, which supplements the United Nations Convention Against Transnational Organized Crime of 2001. Article 3 (a) of the Protocol defines TIP as "the recruitment, transportation, transfer, harboring or receipt of persons, by the threat or use of force, by abduction, fraud, deception, coercion or the abuse of power or by the giving or receiving payments or benefits to achieve the consent of a person having control over another person for the purpose of exploitation. Exploitation shall include, at a minimum, the exploitation of the prostitution of others or other forms of sexual exploitation, forced labor or services, slavery or practices similar to slavery, servitude or the removal of organs." See: UN Convention Against Transnational Organized Crime, Resolution \# A/RES/55/25; www.unodc.org/pdf/crime/a_res_55/res5525e.pdf. 
ture of TIP requires coordination and cooperation in the most sensitive areas of international effort: in crime prevention and information sharing. To address the question effectively, international cooperation is the only solution. However, one of the major obstacles to this solution - especially for states in South Eastern Europe (SEE) and the Western New Independent States (WNIS, including Belarus, Moldova, and Ukraine) - is the low level of trans-border cooperation between security and law enforcement institutions in the affected region.

In addition to the novelty of such crimes in the nations that are making the transition from communism, these states are also going through the process of transformation. Increasing the efficiency of their counter-trafficking policies is dependent on the outcome of overall reforms in the security sector, where such policies are developed and implemented. Three major problems that are playing a significant role in hindering reforms of the security sector and transnational cooperation, relate to the areas of institution building, corruption, and border security.

\section{Assessment of TIP in the SEE and WNIS Region}

The International Organization for Migration (IOM) estimates the number of prostitutes of East European origin currently working in Western Europe at 300,000, and the total number of women and children, purchased or exchanged, arriving in Western Europe every year at $120,000 .^{2}$ Although there are no data on the proportion of women and children arriving annually from individual nations in Eastern Europe, according to the IOM and EUROPOL, the principal source countries today are Moldova (providing up to 80 percent of the traffic; many Moldovan villages do not have any women between the ages of 18 and 30), Bulgaria, Romania, and Ukraine. The destination points for Moldovan trafficked persons are Bosnia and Herzegovina $(\mathrm{BiH})$, Macedonia, Albania, Serbia, Montenegro, Kosovo, Italy, France, Portugal, Germany, Romania, Bulgaria, Hungary, Slovakia, Czech Republic, Poland, Greece, Cyprus, Russia, Turkey, Lebanon, Israel, U.A.E., Syria, Pakistan, and Afghanistan (see Table 1).

Flows of trafficked persons from Bulgaria and Romania are directed to Southern and Western Europe, and women and children from Ukraine are trafficked worldwide (see Table 1). While the Ukrainian Ministry of the Interior estimated in 2001 that 100,000 Ukrainian women were trafficked over the preceding ten years, the IOM estimated the number to be four times higher. ${ }^{3}$ The problem is accentuated for Ukraine and Moldova given that persons from these nations are also trafficked to be exploited for their labor in Western Europe, North America, Russia, and neighbor states. Different sources state that the number of Ukrainians working abroad is anywhere from five to eight million. How many of them might qualify as victims of traffickers is unknown.

2 The latter figure includes both women from Eastern Europe and those coming from Africa (Nigeria), Asia (including Central Asia; Osh in Kyrgyzstan is a crossroads for this traffic), and Latin America (Brazil).

3 D. Hughes, "The 'Natasha' Trade: The Transnational Shadow Market of Trafficking in Women," National Institute of Justice Journal 246 (2001): 10. 
Given that the number of people trafficked annually is at least in the hundreds of thousands, if not in the millions, number of TIP cases that have actually been prosecuted is very low. As was reported by the Ukrainian Ministry of the Interior, 873 trafficking cases were filed from 1998 to 2004 (cases falling under Article 149 of the Criminal Code of Ukraine of 2001). ${ }^{4}$ According to the judge of the Supreme Court of Ukraine, from 1998 to 2003, more than six hundred cases were filed, and ninety-four were sent to trial. ${ }^{5}$ The U.S. State Department's Trafficking in Persons Report of 2004 states that in 2003 Ukrainian prosecutors tried forty-one trafficking cases and convicted traffickers in twenty-nine cases. Those twenty-nine cases involved thirty-two defendants. ${ }^{6}$

Certainly, the positive fact is that the number of the filed cases increased noticeably, from only two in 1998 to 269 in 2004; however, the limited data available show that police and law enforcement institutions are unprepared to combat criminal networks that have a hierarchical structure, well-defined roles within this structure, and that are often involved in several different types of criminal activities. The problem is also complicated by the persistent lack of funding (see Box 1) and the inadequacy of preventive strategies. Just as one example, the Interdepartmental Coordination Council for Combating Trafficking in Persons has had no formal meetings since its establishment in December 2002.

In the early 1990s, Lithuania, Poland, the Czech Republic, and Hungary were the first source countries for trafficked persons following the fall of communism, along with Russia and Ukraine. Those countries have since become transit and destination points (see Table 1). In this they join the countries of the European Union (EU), but also the states of the Balkans, where the presence of foreign troops and armed conflict provided a substantial market throughout the 1990s and continues to make an extensive contribution to the traffic. According to the NATO Rapporteur Christine Boutin, trafficking networks used various routes, including:

- The route that passes through Romania, Serbia (which features five "women markets" in Belgrade and the Novi-Sad trading center), Bosnia and Herzegovina (the Brcko Arizona market), Croatia, and Austria, and then on to the Czech Republic, Poland, and Scandinavia, or to Germany, France, and the United Kingdom

- The route that passes through Kosovo, Albania, the former Yugoslav Republic of Macedonia (the village of Veledze is the regional center of prostitution) and Montenegro, then through Italy.

In total, of the 500,000 women who are victims of criminal trafficking networks around the world every year, 200,000 pass through the Balkans. Of these 200,000 women, some 80,000 are destined for the Middle East, Asia, and North America.?

4 Korrespondent 146:7 (26 February 2005), 57.

5 Protydiya suchasnym formam rabstva, Supreme Court of Ukraine; available at www.scourt.gov.ua/clients/vs.nsf/0/AAFA3E253C0416D9C3256F9D00475B0F.

6 Ukraine (Tier 2) (Extracted from U.S. State Department Trafficking in Persons Report, 14 June 2004); available at www.state.gov/g/tip/rls/tiprpt/2004/33192.htm.

7 C. Boutin, 141 CCDG 03 E - Organized Crime - Drug and Human Trafficking in Europe, NATO Parliamentary Assembly (2004); available at www.nato-pa.int/Default.asp?SHORTCUT=368. 
Changing this situation in the region will require coordinated actions aimed at pursuing joint strategies in both source and transit countries. In geographical terms, the area in question covers territory stretching from Ukraine in the east to the Balkan states in the southwest. As source countries, Ukraine and Moldova have some experience in combating TIP within their own domestic borders, but their participation in joint regional efforts is limited. ${ }^{8}$ Following the eastward enlargement of the EU in May 2004 and January 2007, these countries have become direct neighbors of the EU. As a result, their territories are rapidly becoming part of the transit route for traffickers from Russia, the Caucasus, and Central Asia. As a result, stability in the region has turned to be a significant concern for the EU states. The existence of the Transdniestria enclave in the region exacerbates the problem of effective counter-trafficking measures. As both transit and destination countries, the Balkan states have had some experiences of closer cooperation with each other

\section{Box 1. Funding and counter traf- ficking in Ukraine}

The money made from the sexual exploitation and enslavement of trafficked women enriches transnational criminal networks. According to $\mathrm{Mi}$ chael Platzer, of the United Nations Center for International Crime Prevention, trafficking in women has one of the highest profit margins and lowest risks for criminal groups in Eastern Europe. Michail Lebed, chief of criminal investigations for the Ukrainian Ministry of the Interior, told the Kiev Post, "It is a human tragedy, but also, frankly, a national crisis. Gangsters make more money from these women in a week than we have in our law enforcement budget for the whole year."

See: Hughes, "The 'Natasha' Trade," 13. within the framework of programs and strategies developed by various international organizations. The intensification of trans-border and trans-regional cooperation between source and transit states in the area including the SEE states and WNIS would potentially work toward reducing the level of soft security threat facing Europe.

\section{TIP and Corruption}

One of the key lessons learned from the counter-trafficking activities in the SEE and WNIS region is the recognition of the fact that police alone cannot tackle the problem effectively. Groups involved in TIP are more often than not a part of the broader transnational criminal networks, which makes it essential to use the security services (especially intelligence units) and paramilitary groups for domestic counter-trafficking actions. However, the deployment of security services or paramilitary units for domestic objectives contradicts the basic principles of democratic transition. While in the WNIS efforts need to be made to extricate the security services from domestic politics, their participation in counter-trafficking efforts might be of crucial importance for promoting international co-

8 Moldova and Ukraine participated in international operations Mirage, Mirage-3, and Mirage-4, which were organized under the rubric of the Southeast European Cooperative Initiative (SECI) to combat human trafficking in the SEE region. The issue of establishing a counter-trafficking center in Chisinau, Moldova, for the members of GUUAM (Georgia, Ukraine, Uzbekistan, Azerbaijan, and Moldova) was discussed with the U.S. Department of State. 
operation. To balance security and democratic values is extremely difficult when the entire security sector has to be reformed, reduced, and placed under civil control.

Another problem, which makes both internal counter-trafficking operations and effective international cooperation even more difficult, is the level of corruption in transition societies (see Box 2). The NIS states have the highest levels of corruption as estimated by the NGO Transparency International (see Table 1). If the Balkan states' struggle against corruption was placed within the general framework of conditions established by international organizations, and was periodically checked with a range of inspection instruments, the WNIS states have never been a part of any binding verification system. All countries of South Eastern Europe are now members of the Group of States Against Corruption (GRECO), under which their compliance with European anti-corruption instruments is monitored. Some also participate in the OECD monitoring mechanism. In all countries in the region, comprehensive anti-corruption plans have been adopted and are under implementation. Some countries have created institutional mechanisms to manage the implementation of these plans as well as specialized institutions to investigate and prosecute corruption. The capacity of civil society organizations to support anti-corruption measures has been strengthened, as reflected in some countries in the formation of anti-corruption coalitions or the creation of national chapters of Transparency International.

In the WNIS, corruption is flourishing in the security services, military, police, border security bodies, law enforcement institutions, and all relevant central and local government structures. ${ }^{9}$ Corruption not only impedes law enforcement, but also jeopardizes information sharing with Western partners, since sensitive information might go directly to the criminal targets of counter-trafficking operations.

Corruption is the most difficult barrier to overcome in getting countries to take consistent and coherent actions against organized crime. From low-level bribery to the inappropriate behavior of prime ministers and even presidents, corruption influences all aspects of domestic, external, and security policy in the WNIS. Corruption affects border security by circumventing export controls, eroding institutional authority, and endangering foreign aid packages. ${ }^{10}$ Although the number of proved cases directly linking the issue of military and security sector corruption with the problem of anti-trafficking or transnational criminal

9 Ukrainian Prime Minister Volodymyr Sretovich was unwilling to rule out the possibility that in Ukraine there might be members of the parliament and high officials who shield trafficker groups (see: Press Conference of the Parliamentary Committee for Combating Organized Crime and Corruption, 3 March 2006, Liga Business Inform, at www.liga.net).

10 Katherina Gonzales explained the link between corruption in Ukraine and the cut-off of foreign aid as follows: "There have been problems with international aid packages to Ukraine for more than ten years, stemming from corruption and the derailment of foreign direct investment by corrupt Ukrainian businessmen. The best example of this problem occurred in 1996, when the International Monetary Fund called off its $\$ 1.6$ billion loan to Ukraine. The official reason was that Ukraine had overshot its spending target. However, it was later alleged that the money had been mismanaged from the beginning and that a good portion of it had surreptitiously left the country." See Katherina Gonzales, "Good Fences Make Good Neighbors: Ukrainian Border Security and Western Assistance," Problems of Post-Communism 51:1 (Jan/Feb 2004): 50. 
networks is limited, ${ }^{11}$ high levels of corruption in military, border security bodies, and security sectors of the WNIS have been reported regularly. ${ }^{12}$ The Soviet-era regulations that do not allow border guards to check any cargo addressed to or from the security services have been left unchanged.

\section{Regional Anti-TIP Network}

The porous borders of Ukraine reduce the effectiveness of counter-trafficking operations in the entire region. Ukraine's borders (land and sea combined) extend for a total of $7,445 \mathrm{~km}$. The Ukrainian-Russian border runs almost $1,500 \mathrm{~km}$; the remaining land borders are shared with Hungary, Romania, Poland, Slovakia, Belarus, and Moldova. As of January 2005, Ukraine had signed border treaties with six of its neighbors, and was continuing discussions on the sea border with Russia, the issue of Snake island and the continen-

\section{Box 2: Trafficking and Corruption}

Allegations have been brought against top Montenegrin government officials for their complicity in networks involved in forced prostitution. Six high-ranking government officials and the country's Deputy State Prosecutor were arrested in December 2002. Although the government has given assurances that the case would be fully investigated, all the detained officials have been released from custody.

Reports of official complicity in human trafficking for purposes of sexual exploitation have been continuing in Russia. In 2003, the government reported one anti-corruption action targeting an organized crime group in the Ministry of the Interior suspected of, among other things, protecting prostitution networks.

Sources: World Revolution (global activist social movement for progressive social change), "Sex Trafficking: Facts \& Figures," available at www.worldrevolution.org/Projects/Webguide/Gu ideArticle.asp?ID=1430. U.S. Department of State, Trafficking in Persons Report 2004; available at http://ww.state.gov/g/tip/rls/tiprpt/2004/ 33192.htm. tal shelf with Romania, and border delimitation with Belarus and Moldova. However, the problem of adequate border management is far from being resolved. In the cases of the Russian-Ukrainian and Byelorussian-Ukrainian borders, the border regime is not supported by sufficient infrastructure and maintenance.

Controlling such a vast area and interacting with seven separate governments are burdens that pose a threat to Ukrainian, European, and possibly global security. The United States and the member states of the EU are deeply concerned that Ukraine will be used as a transit point for instruments of terror, including weapons of mass destruction (WMD) and chemical and biological weapons (CBW). Ukraine's illicit transit routes make it an ideal transit point for human trafficking, drug trafficking, small arms trafficking, and smuggling.

Potentially, Ukraine could reinforce efforts in anti-trafficking cooperation with neighboring states-Poland, Hungary, and Slovakia, as well as Moldova and Belarus-

11 See United States of America vs. Ludwig Fainberg, Case Number 97-054, U.S. District Court, Southern District of Florida, discussed in L. Shelley, "Trafficking and Smuggling in Human Beings," presentation at the conference Corruption Within Security Forces: A Threat To National Security, George C. Marshall European Center for Security Studies, 14-18 May 2001, Garmisch-Partenkirchen, Germany.

12 See W. Parchomenko, "Prospects for Genuine Reform in Ukraine's Security Forces," Armed Forces \& Society 28:2 (Winter 2002): 279-308. 
using its experience of trans-border cooperation under the umbrella of the EU programs. Ukraine has also declared regional cooperation within the framework of the Black Sea Economic Cooperation (BSEC) and GUUAM to be a priority. At present, six oblasts of Ukraine-Odeska, Zakarpatska, Lvivska, Ivano-Frankivska, Chernovitska, and Volynska - cooperate with border regions of Poland, Hungary, and Slovakia as well as with two WNIS countries, Moldova and Belarus. Three so-called economic, "euroregions" have been established in the region - Lower Danube, Bug, and Karpatian — with a total population of nearly twenty-four million people. This (primarily economic) mode of cooperation, including joint ventures, cross-border trade, and investments, is far from being fully institutionalized. However, experience in communication and knowledge of the border region might prove advantageous for the development of joint counter-trafficking operations. To be effective in combating all sorts of illegal activities in the region, the capacity of the established regional organizations should be used by means of appropriate structures within the framework of existing organizations. Attempts to reinforce visa regimes from the EU side could lead to opposite results, however. Such reinforcement would decrease the potential for legal business in the region and create conditions for the growth of criminal networks involving smugglers and traffickers.

The Ukrainian government declared the priorities of Ukraine's integration into NATO and EU. The first attempts to combat corruption in the state's customs agency structures have been made through the adoption of a governmental anti-corruption program. The promise to abolish visa requirements for all citizens of the EU states and the U.S. has been made as a gesture of good will.

The importance of these steps should not be underestimated. However, any initiatives intended to change the international climate around Ukraine have to be supplemented by comprehensive reform programs in all spheres, and most importantly in the security sector.

To ensure effectiveness in counter-trafficking operations, a zero tolerance policy toward TIP was included in the NATO-Ukraine Target Action Plan for 2005. The measures for this reinforced level of cooperation were added to the EU-Ukraine Action Plan within the framework of a specific EU Action Plan on Justice and Home Affairs (JHA) with Ukraine of 10 December 2001. The EU Action Plan on JHA with Ukraine set up a Scoreboard as a tool for the implementation, monitoring, evaluation, and definition of annual priorities. It is defined that the Neighborhood Policy will be based on this EU Action Plan on Justice and Home Affairs with Ukraine and its implementing Scoreboard. The priorities for cooperation in the field of Justice and Home Affairs will be defined on an annual basis by the EU-Ukraine JHA Ministerial Troika meeting.

The first EU-Ukraine JHA Ministerial Troika of November 2002 assigned priority in cooperation on JHA to readmission and migration, border management, money laundering, trafficking in human beings, and drugs as well as corruption, preventing and fighting sexual exploitation of women and children, and child pornography. In follow-up efforts to the Action Plan, a JHA group has been established in Kiev, consisting of JHA-attachés, Liaison Officers, and consular staff representing the member states and the commission in the JHA area.

The EU-Ukraine Action Plan under the European Neighborhood Policy, which was formally endorsed by the EU-Ukraine Cooperation Council on 21 February 2005, emphasizes that a constructive dialogue on visa facilitation regimes between the EU and Ukraine 
will be established, with a view to preparing for future negotiations on a visa facilitation agreement, taking into account the need for progress on the ongoing negotiations for an EC-Ukraine readmission agreement. ${ }^{13}$ According to the JHA Action Plan, the EU Council was to review the operation of this plan towards the end of 2007, and may decide to carry out further reviews in relation to this matter. Based upon such reviews and developments in Ukraine, new objectives and actions could be added to the Action Plan with Ukraine in the context of the European Neighborhood Policy.

Finally, the conclusion can be made that a new approach to combating human trafficking in the region is needed. Such an approach has to consider three key elements:

- Regional alterations in TIP patterns

- Experience of fighting TIP in SEE countries

- Political changes in the WNIS region.

The previous strategies, which aimed to fight the crime of human trafficking in source, transit, and destination countries separately, have provided insufficient ground for the development of transnational cooperation in this field. Partial reforms in the security sector, inadequate measures to reduce corruption in governmental bodies, and delayed plans to implement comprehensive political and economic reforms have hindered regional transformation. Apparently, raising awareness alone is not an adequate measure to stop trafficking when poverty and the lack of opportunities continue to be the driving forces behind the phenomenon. Combating trafficking effectively means channeling security sector reform efforts in unison with Western standards and with the help of the international community.

${ }^{13}$ Ukraine and the EC launched joint work on the project Readmission Agreement during consultations held in Brussels in March 2002. 
Table 1. CEE, SEE, and NIS: Corruption rating as defined by Transparency International Corruption Perceptions Index (TI CPI), Compliance with the U.S. Trafficking Victims Protection Act (TVPA), and Source, Transit, and Destination Flows, 2004-07 ${ }^{14}$

\begin{tabular}{|c|c|c|c|c|c|c|c|c|c|}
\hline \multirow[t]{2}{*}{ COUNTRY } & \multicolumn{2}{|c|}{ 氞. } & \multirow{2}{*}{ ڤ } & \multirow{2}{*}{ ב } & \multirow{2}{*}{ 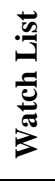 } & \multirow[t]{2}{*}{ Source } & \multirow[t]{2}{*}{ Transit } & \multirow[t]{2}{*}{ Destination } & \multirow[t]{2}{*}{ 胥苞苞 } \\
\hline & 2004 & 2007 & & & & & & & \\
\hline Estonia & 32 & 28 & & + & + & $\begin{array}{l}\text { Finland, Sweden, Norway, } \\
\text { Germany }\end{array}$ & $\mathrm{n} / \mathrm{s}$ & $\mathrm{n} / \mathrm{s}$ & + \\
\hline Slovenia & 33 & 27 & & & + & $\begin{array}{l}\text { Italy, Germany, Greece, Portugal, } \\
\text { Spain, Netherlands }\end{array}$ & $\begin{array}{l}\text { Eastern Europe and the } \\
\text { Balkans }\end{array}$ & $\mathrm{n} / \mathrm{a}$ & \\
\hline Hungary & 42 & 39 & & & & Western Europe, U.S. & $\begin{array}{l}\text { Russia, Romania, Ukraine, } \\
\text { Moldova, Bulgaria, the } \\
\text { Balkans, Iraq, Pakistan, } \\
\text { Bangladesh, Afghanistan }\end{array}$ & $\begin{array}{l}\text { Russia, Romania, } \\
\text { Ukraine, Moldova, } \\
\text { Bulgaria, the Balkans }\end{array}$ & \\
\hline Lithuania & 44 & 51 & + & & & $\begin{array}{l}\text { Germany, Spain, Denmark, } \\
\text { Norway, Netherlands, U.K., } \\
\text { France, Poland }\end{array}$ & $\begin{array}{l}\text { Germany, Spain, Denmark, } \\
\text { Norway, Netherlands, U.K., } \\
\text { France, Poland }\end{array}$ & $\begin{array}{l}\text { Ukraine, Russia, } \\
\text { Belarus }\end{array}$ & + \\
\hline $\begin{array}{l}\text { Czech } \\
\text { Republic }\end{array}$ & 50 & 41 & + & & & $\begin{array}{l}\text { Western Europe, U.S., Japan, } \\
\text { Mexico }\end{array}$ & $\begin{array}{l}\text { Russia, Belarus, Ukraine, } \\
\text { Moldova, the Balkans, Asia }\end{array}$ & $\begin{array}{l}\text { Russia, Belarus, } \\
\text { Ukraine, Moldova, the } \\
\text { Balkans, Asia }\end{array}$ & \\
\hline Bulgaria & 54 & 54 & & + & & $\begin{array}{l}\text { Western, Southern, and Eastern } \\
\text { Europe }\end{array}$ & $\begin{array}{l}\text { Ukraine, Romania, } \\
\text { Moldova, Russia, } \\
\text { Uzbekistan }\end{array}$ & $\mathrm{n} / \mathrm{s}$ & \\
\hline Latvia & 57 & 51 & & + & & $\begin{array}{l}\text { U.K., Poland, Spain, Germany, } \\
\text { Italy }\end{array}$ & $\mathrm{n} / \mathrm{s}$ & $\mathrm{n} / \mathrm{s}$ & + \\
\hline
\end{tabular}

14 Source, Transit, and Destination Flows indicates routes of trafficking in persons from, through, and to destinations for each country of the region.

15 Tier 1: countries that fully comply with the TVPA minimum standards for the elimination of trafficking. Tier 2: countries that do not fully comply with the minimum standards but are making significant efforts to bring themselves into compliance. Tier 2 Watch List: countries with Tier 2 status requiring special scrutiny because of a high or significantly increasing number of victims; failure to provide evidence of increasing efforts to combat trafficking in persons; or an assessment of Tier 2 status based on commitments to take action over the next year. 


\begin{tabular}{|c|c|c|c|c|c|c|c|c|c|}
\hline Slovakia & 58 & 49 & & & & $\begin{array}{l}\text { Austria, Netherlands, France, } \\
\text { Spain, Switzerland, Italy, Greece, } \\
\text { Slovenia, Czech Republic, Japan }\end{array}$ & The Balkans, FSU states & $\mathrm{n} / \mathrm{s}$ & \\
\hline Croatia & 67 & 64 & & + & + & Germany, Italy & $\begin{array}{l}\text { Ukraine, Moldova, Roma- } \\
\text { nia, Hungary, Bulgaria, } \\
\text { BiH, Slovakia }\end{array}$ & $\mathrm{BiH}$ & \\
\hline Poland & 69 & 61 & + & & & $\begin{array}{l}\text { Germany, Italy, Belgium, France, } \\
\text { Netherlands, Japan, Israel }\end{array}$ & $\begin{array}{l}\text { Ukraine, Bulgaria, Romania, } \\
\text { Belarus, Moldova, Russia }\end{array}$ & $\mathrm{n} / \mathrm{s}$ & + \\
\hline Belarus & 74 & 150 & & + & & $\begin{array}{l}\text { Western, Central, and Southern } \\
\text { Europe; Russia, Baltic states, } \\
\text { Japan, Israel, Syria, Lebanon, } \\
\text { U.A.E. }\end{array}$ & $\mathrm{n} / \mathrm{s}$ & $\mathrm{n} / \mathrm{a}$ & \\
\hline Armenia & 82 & 99 & & + & & U.A.E., Turkey, Russia, Greece & Uzbekistan & $\mathrm{n} / \mathrm{a}$ & + \\
\hline $\begin{array}{l}\text { Bosnia and } \\
\text { Herzegovina }\end{array}$ & 83 & 84 & & + & + & Western Europe & $\begin{array}{l}\text { Moldova, Ukraine, Roma- } \\
\text { nia, Russia, Belarus, SaM }\end{array}$ & $\begin{array}{l}\text { Moldova, Ukraine, } \\
\text { Romania }\end{array}$ & + \\
\hline Romania & 89 & 69 & & & & $\begin{array}{l}\text { Spain, Portugal, Italy, } \\
\text { Netherlands, Austria, France, } \\
\text { Germany, U.K., Hungary }\end{array}$ & Moldova, Ukraine, Russia & $\mathrm{n} / \mathrm{s}$ & \\
\hline Russia & 95 & 143 & & + & + & Worldwide & $\begin{array}{l}\text { Moldova, Ukraine, Belarus, } \\
\text { Georgia, Armenia, } \\
\text { Azerbaijan, Kazakhstan, } \\
\text { Kyrgyzstan, Uzbekistan, } \\
\text { Tajikistan }\end{array}$ & $\begin{array}{l}\text { Moldova, Ukraine, } \\
\text { Belarus, Georgia, } \\
\text { Armenia, Azerbaijan, } \\
\text { Kazakhstan, Kyr- } \\
\text { gyzstan, Uzbekistan, } \\
\text { Tajikistan }\end{array}$ & \\
\hline $\begin{array}{l}\text { FYR } \\
\text { Macedonia }\end{array}$ & 99 & 84 & + & & & Western Europe & $\begin{array}{l}\text { Ukraine, Moldova, } \\
\text { Romania, Bulgaria, Albania, } \\
\text { SaM, Kosovo, Western } \\
\text { Europe }\end{array}$ & $\begin{array}{l}\text { Ukraine, Moldova, } \\
\text { Romania, Bulgaria }\end{array}$ & \\
\hline $\begin{array}{l}\text { Serbia and } \\
\text { Montenegro* }\end{array}$ & 101 & $\begin{array}{l}79 / \\
84\end{array}$ & & + & + & Italy, Germany & $\begin{array}{l}\text { Kosovo, Bosnia, Croatia, } \\
\text { Albania, Italy, Germany }\end{array}$ & $\begin{array}{l}\text { Moldova, Ukraine, } \\
\text { Russia, Romania, } \\
\text { Bulgaria }\end{array}$ & + \\
\hline Albania & 108 & 105 & & + & & $\begin{array}{l}\text { Greece, Italy, U.K., France, } \\
\text { Netherlands }\end{array}$ & $\begin{array}{l}\text { Greece, Italy, U.K., France, } \\
\text { Netherlands, Spain }\end{array}$ & $\begin{array}{l}\text { Moldova, Ukraine, } \\
\text { Russia, Belarus }\end{array}$ & \\
\hline
\end{tabular}




\begin{tabular}{|c|c|c|c|c|c|c|c|c|}
\hline Moldova & 117 & 111 & + & & $\begin{array}{l}\text { BiH, Macedonia, Albania, SaM, } \\
\text { Kosovo, Italy, France, Portugal, } \\
\text { Germany, Romania, Bulgaria, } \\
\text { Hungary, Slovakia, Czech } \\
\text { Republic, Poland, Greece, } \\
\text { Cyprus, Russia, Turkey, } \\
\text { Lebanon, Israel, U.A.E., Syria, } \\
\text { Pakistan, Afghanistan }\end{array}$ & Ukraine & $\mathrm{n} / \mathrm{a}$ & \\
\hline Uzbekistan & 119 & 175 & + & + & $\begin{array}{l}\text { U.A.E., Kuwait, Bahrain, India, } \\
\text { Malaysia, South Korea, Japan, } \\
\text { Thailand, Kazakhstan, Russia, } \\
\text { Western Europe }\end{array}$ & $\begin{array}{l}\text { Central Asia, Russia, } \\
\text { Ukraine }\end{array}$ & $\mathrm{n} / \mathrm{a}$ & + \\
\hline Kazakhstan & 124 & 150 & + & + & $\begin{array}{l}\text { Russia, U.A.E., Turkey, Israel, } \\
\text { Greece, South Korea, Syria }\end{array}$ & $\begin{array}{l}\text { Russia, U.A.E., Turkey, Is- } \\
\text { rael, Greece, South Korea, } \\
\text { Czech Republic, Romania, } \\
\text { Syria, Germany, Spain, } \\
\text { Italy, Cyprus, Netherlands, } \\
\text { Portugal, Ireland }\end{array}$ & $\begin{array}{l}\text { Kyrgyzstan, Uzbekistan, } \\
\text { Tajikistan }\end{array}$ & + \\
\hline Kyrgyzstan & 125 & 150 & & & Kazakhstan, Russia & $\begin{array}{l}\text { Kazakhstan, Russia, U.A.E., } \\
\text { South Korea, China }\end{array}$ & $\mathrm{n} / \mathrm{a}$ & + \\
\hline Ukraine & 128 & 118 & + & & Worldwide & $\begin{array}{l}\text { Moldova, Russia, Central } \\
\text { Asia }\end{array}$ & $\mathrm{n} / \mathrm{a}$ & \\
\hline Georgia & 136 & 79 & + & + & $\begin{array}{l}\text { Russia, Ukraine, Greece, Israel, } \\
\text { Turkey, Western Europe }\end{array}$ & $\begin{array}{l}\text { Russia, Greece, Israel, } \\
\text { Turkey, Western Europe }\end{array}$ & & \\
\hline Tajikistan & 138 & 150 & + & + & Russia, Central Asia, Gulf States & Central Asia States & $\mathrm{n} / \mathrm{a}$ & \\
\hline Azerbaijan & 140 & 150 & + & + & U.A.E, Turkey, Pakistan & Russia, Central Asia States & $\mathrm{n} / \mathrm{a}$ & + \\
\hline
\end{tabular}

* Serbia and Montenegro corresponds to the name of the country in 2004. For 2007, the CPI index evaluates Serbia and Montenegro separately.

Sources: U.S. Department of State, Office to Monitor and Combat Trafficking in Persons, Trafficking in Persons Report 2004 (14 June 2004); Trafficking in Persons Interim Assessment Report of the progress made by countries on the September 2007 Special Watch List to combat trafficking in persons since the June 2004 annual report; Transparency International Corruption Perceptions Index, 2007. 
THE QUARTERLY JOURNAL

\section{Bibliography}

Gonzales, Katherina. Good Fences Make Good Neighbors: Ukrainian Border Security and Western Assistance In Problems of Post-Communism ., 2004.

Hughes, D.. "The 'Natasha' Trade: The Transnational Shadow Market of Trafficking in Women." National Institute of Justice Journal 246 (2001).

Parchomenko, W. "Prospects for Genuine Reform in Ukraine's Security Forces." Armed Forces \& Society 28, no. 2 (2002): 279-308.

Shelley, L. Trafficking and Smuggling in Human Beings In Corruption Within Security Forces: A Threat To National Security. Garmisch-Partenkirchen, Germany: George C. Marshall European Center for Security Studies, 2001. 